\title{
Opinion \\ The Role of Vitamin K in Cirrhosis: Do Pharmaco-K-Netics Matter?
}

\author{
Stephanie Jin, Lisa Hong (1) and Alireza FakhriRavari *(D)
}

Department of Pharmacy Practice, School of Pharmacy, Loma Linda University, Loma Linda, CA 92350, USA; SYJin@llu.edu (S.J.); lhong@llu.edu (L.H.)

* Correspondence: afakhriravari@llu.edu

Citation: Jin, S.; Hong, L.;

FakhriRavari, A. The Role of Vitamin

$\mathrm{K}$ in Cirrhosis: Do Pharmaco-

K-Netics Matter? Gastrointest. Disord. 2022, 4, 15-21. https://doi.org/

10.3390 /gidisord 4010003

Academic Editor: Consolato M. Sergi

Received: 7 January 2022

Accepted: 24 January 2022

Published: 3 February 2022

Publisher's Note: MDPI stays neutral with regard to jurisdictional claims in published maps and institutional affiliations.

Copyright: (C) 2022 by the authors. Licensee MDPI, Basel, Switzerland. This article is an open access article distributed under the terms and conditions of the Creative Commons Attribution (CC BY) license (https:// creativecommons.org/licenses/by/ $4.0 /)$.

\begin{abstract}
Patients with advanced liver disease who are not taking vitamin $\mathrm{K}$ antagonists often have an elevated international normalized ratio, potentially due to vitamin $\mathrm{K}$ deficiency and the decreased synthesis of clotting factors by the liver. It is possible that vitamin K deficiency is due to dietary deficiency, impaired absorption in the small intestine, or both. This has led to the practice of the administration of phytonadione to limit the risks of bleeding in these patients. However, phytonadione is available in different formulations with varying pharmacokinetics and there is a paucity of data in the literature to guide optimal management. The routine use of phytonadione to correct INR in cirrhotic patients not taking warfarin should be avoided due to the lack of proven benefits. However, intravenous phytonadione may be considered in actively bleeding or critically ill patients with vitamin $\mathrm{K}$ deficiency. Oral formulation is unlikely to be absorbed in cirrhotic patients and should be avoided.
\end{abstract}

Keywords: cirrhosis; liver disease; phytonadione; vitamin K

The management of coagulopathy secondary to liver cirrhosis is an ongoing and debated issue. Liver plays a crucial role in hemostasis, and advanced cirrhosis causes several pathophysiological changes that may appear as coagulopathic imbalances [1]. The cause of this apparent hemostatic imbalance is attributed to six proposed mechanisms: the decreased synthesis of pro and anticoagulant proteins by the liver, impaired clearance of clotting factor VIII and the von Willebrand factor, platelet disorders, nutritional deficiency (e.g., vitamin K deficiency), fibrinolysis, and disseminated intravascular coagulation. As a result, patients with end stage liver disease (ESLD) commonly present with a prolonged prothrombin time (PT) and an elevated international normalized ratio (INR). This is concerning because the incidence of bleeding and its associated mortality is high in patients with advanced cirrhosis [2-4], but the majority of clinically significant bleeding episodes in cirrhotic patients seem to be due to increased portal venous pressure rather than altered hemostasis $[5,6]$. INR is a standardization of PT, which evaluates coagulation in the body [7]. However, the International Sensitivity Index used for standardization was developed for vitamin $\mathrm{K}$ antagonists, specifically [8]. As a liver function test, INR can be useful to determine the severity of cirrhosis as it takes into consideration clotting factors I (fibrinogen), II, V, VII, and IX, all synthesized by the liver [7]. However, INR has not been validated to predict bleeding risks in cirrhotic patients and is poorly correlated with bleeding in this population [9]. Multiple randomized clinical trials have shown that the treatment of cirrhotic patients with recombinant activated factor VII correct PT and INR, but fail to control bleeding [10-13]. Moreover, hemostasis may still be balanced because the synthesis of both procoagulant (e.g., clotting factors) and anticoagulant (e.g., protein C, antithrombin) proteins is reduced $[9,14]$. There is also evidence that thrombin levels in patients with cirrhosis are similar to healthy individuals $[15,16]$. In fact, cirrhotic patients may have an increased risk of venous thromboembolism and portal vein thrombosis [17-20]. In 
addition to the impaired ability of the cirrhotic liver to produce some of the clotting factors, vitamin $\mathrm{K}$ deficiency can exacerbate the problem [21].

Vitamin $\mathrm{K}$, a group of fat-soluble vitamins, is required to produce clotting factors. Vitamin $\mathrm{K}_{1}$, a phylloquinone, is obtained from dietary sources (e.g., green leafy vegetables), whereas vitamin $\mathrm{K}_{2}$, a menaquinone, is synthesized by bacteria in the small intestine [22]. Healthy individuals can absorb $40-70 \%$ of vitamin $\mathrm{K}_{1}$ from the jejunum and ileum, similar to other fat-soluble vitamins [23-26]. Aiding in the production of factors II, VII, IX, X, protein $\mathrm{C}$, and $\mathrm{S}$, vitamin $\mathrm{K}$ plays a large role in the coagulation process. Vitamin $\mathrm{K}$ deficiency is a portion of the proposed mechanism of elevated INR in cirrhotic patients through dietary deficiency (common in alcohol-induced liver disease or chronic illness) and reduced absorption in the small intestine, likely due to decreased bile flow, impaired vitamin $\mathrm{K}$ cycle, and increased use of antibiotics, which reduce the vitamin K produced by normal gastrointestinal flora $[14,27,28]$. Extrahepatic biliary obstruction and pancreatic insufficiency can further reduce absorption of vitamin K [23]. However, it is important to note that while bile production and vitamin $\mathrm{K}$ absorption may be decreased in patients with cirrhosis, not all cirrhotic patients with increased INR have a vitamin $\mathrm{K}$ deficiency. Vitamin K deficiency is reportedly present in $<15 \%$ of patients with cirrhosis [24]. Repletion of vitamin $\mathrm{K}$ attempts to correct this factor imbalance by restoring normal levels of this component to generate coagulation factors [14]. This elevated INR and potential vitamin K deficiency led to the practice of administration of vitamin $\mathrm{K}$ to limit the risks of bleeding.

Phytonadione (vitamin $\mathrm{K}_{1}$ ) has multiple administration forms, including oral (PO), intravenous (IV), intramuscular (IM), and subcutaneous (SQ). While IV and PO formulations are commonly used for reversal of supratherapeutic vitamin $\mathrm{K}$ antagonists (e.g., warfarin), SQ and IM formulations are commonly avoided due to absorption variability and risk of hematoma, respectively [29,30]. In general, SQ formulation has a reasonable effect, albeit slow, in reversing INR in patients on warfarin [31-33], with a similar effect as IV formulation at $72 \mathrm{~h} \mathrm{[34].} \mathrm{Although} \mathrm{the} \mathrm{IV} \mathrm{formulation} \mathrm{has} \mathrm{a} \mathrm{faster} \mathrm{onset} \mathrm{of} \mathrm{action,} \mathrm{it}$ carries a risk of fatal hypersensitivity reactions with an incidence of approximately 3 per 10,000 doses [35], unlike the PO and SQ formulations. These hypersensitivity reactions may be more likely when IV phytonadione is administered too quickly at higher doses, with inadequate dilution or formulated with a polyoxyethylated castor oil vehicle [30]. However, anaphylaxis was reported with infusion rates of $1 \mathrm{mg} / \mathrm{min}$ [36]. While the 2019 American Gastroenterological Association (AGA) clinical practice update on coagulation in cirrhosis states that either PO or IV vitamin K may be given to correct hemostatic defects in patients with cirrhosis and vitamin K deficiency [AGA 2019], for cirrhotic patients, it is prudent to avoid the PO formulation due to impaired absorption, as described above. This is further supported in a study conducted by Pereira et al., which concluded that when administered intravenously, vitamin $\mathrm{K}$ had superior absorption and the ability to reverse vitamin $\mathrm{K}$ deficiency, compared to the $\mathrm{PO}$ formulation [37]. Of note, the statement in the AGA clinical practice update regarding the use of $\mathrm{PO}$ vitamin $\mathrm{K}$ is not cited [AGA 2019]. Among the cirrhotic patients, vitamin K $10 \mathrm{mg}$ IV for up to three days was reported as adequate to correct vitamin $\mathrm{K}$ deficiency [38] and this is often seen in clinical practice; however, significant reductions in INR were only observed after the first dose in a study by Sulaiman et al. [39]. The monitoring of the initial doses of vitamin $\mathrm{K}$ is essential in helping to determine whether a patient is vitamin $\mathrm{K}$ deficient-if INR improves, this is indicative of vitamin K deficiency; if INR remains the same, further administration of vitamin K would likely not be beneficial.

While phytonadione is commonly used to reverse the anticoagulant warfarin (a vitamin $\mathrm{K}$ antagonist), its use in cirrhotic patients who are not on warfarin has not been standardized in practice due to differing and scarce literature (Table 1). Alperin and colleagues reported that vitamin $\mathrm{K}$ supplementation corrected coagulopathy in all 42 patients with a vitamin $\mathrm{K}$ deficiency, but it is unclear what proportion of patients had cirrhosis and how the successful correction of coagulopathy was determined [40]. Another small study by Pereira et al. randomized 49 patients with severe acute liver disease to vitamin 
$\mathrm{K} 10 \mathrm{mg}$ IV, PO or placebo and concluded that a single dose of IV vitamin K corrected vitamin K deficiency at 48 and $96 \mathrm{~h}$; however, all the patients had acute liver dysfunction (not cirrhosis) [37]. Saja et al. compared $10 \mathrm{mg}$ SQ vitamin $\mathrm{K}$ in 4 groups of patients with advanced liver disease, including 24 patients with cirrhosis to no vitamin K among 39 health individuals, and demonstrated the minimal (likely clinically insignificant) effects of vitamin K administration on coagulation parameters, such as PT and PTT [41]. In adults with cirrhosis, Rivosecchi and colleagues evaluated the effect of IV vitamin K ( $81 \%$ received $10 \mathrm{mg}$ ) on INR and observed a mean INR decrease of 0.3 with $62.3 \%$ of patients failing to achieve even a $10 \%$ reduction in INR [42]. Meyer et al. evaluated vitamin K administered orally or parenterally (IV or SQ), compared with no vitamin K administration, and similarly found no significant effect on INR (the mean decrease in those considered responders was 0.2) [43]. Most recently, Sulaiman et al. showed that an initial dose of vitamin K was effective at reducing INR with a median decrease of 0.63 in critically ill adult patients with liver disease and a baseline INR of at least 1.5 [39]. Of note, subsequent doses of vitamin $\mathrm{K}$ were not associated with significant decreases in INR. Sulaiman and colleagues demonstrated no difference in bleeding between those who received vitamin $\mathrm{K}$ (various routes used, but more than $90 \%$ of patients received IV) and those who did not, and no difference in venous thromboembolism (VTE) after the adjustment for the propensity score (OR 2.4 (95\% CI 0.45-13.12)). The propensity score for the use of vitamin $\mathrm{K}$ was based on the disease severity scores and the use of pharmacological VTE prophylaxis to reduce the risk of bias when comparing the groups, due to the observational study design. However, the incidence of VTE was greater among those who received vitamin K (17.0 vs. 3.9\%, $p=0.04)$ and was more probable when cumulative doses of vitamin $\mathrm{K}$ reached or exceeded $35.3 \mathrm{mg}$. Furthermore, the group that received vitamin $\mathrm{K}$ had a higher incidence of 30-day mortality (61.7 vs. $13.7 \%, p<0.01$; OR 2.7 (95\% CI 0.79-9.01)), a longer ICU stay (median 10 vs. 4 days, $p<0.01$; OR 0.67 (95\% CI 0.22-1.12)), and longer duration of mechanical ventilation (median 3 vs. 0 days, $p<0.01$; OR 0.93 (95\% CI 0.23-1.62)), highlighting the importance of weighing risks versus benefits. A case series of 5 patients, reported by Aldrich et al., further highlights the variable and unpredictable effects of vitamin K (PO or IV) in patients with cirrhosis [1]. Despite common practice today, the literature for vitamin K administration, specifically in cirrhotic patients, demonstrates minimal to no reduction in the surrogate marker, INR.

Due to the lack of supporting literature, as seen in the studies described above, it remains unclear whether the administration of phytonadione is clinically beneficial in cirrhotic patients and its routine use to correct INR should be avoided because of the potential risks (e.g., hypersensitivity reactions and increased thrombosis) and lack of proven benefits (Table 2). However, given the limited data and the proposed benefits of correcting underlying vitamin K deficiency, IV vitamin K should be carefully considered in critically ill cirrhotic patients or those with active bleeding, to assist in correcting potential vitamin $\mathrm{K}$ deficiencies. Various studies suggest that patient response to a single dose of vitamin $\mathrm{K}$ could be an indicator of a true deficiency; due to this, patients who respond should continue with the therapy whereas non-responders would lack any benefits. PO vitamin $\mathrm{K}$ is unlikely to be absorbed in cirrhotic patients and is best to be avoided. 
Table 1. Studies evaluating the use of vitamin K.

\begin{tabular}{|c|c|c|c|c|c|}
\hline Study & Design & Population & Intervention & Limitations & Conclusion \\
\hline Alperin [40] (1987) & $\begin{array}{l}\text { Retrospective cohort, } \\
\text { multicenter }\end{array}$ & $\begin{array}{c}\mathrm{N}=42 \\
\text { Critically ill patients, } 17 \text { to } \\
78 \text { years old with a vitamin } \mathrm{K} \\
\text { deficiency (prolonged PTs) - } 36 \% \\
\text { with abnormal liver function tests }\end{array}$ & $\begin{array}{l}20-25 \mathrm{mg} \text { IV vitamin K once } \\
\text { followed by } 5 \mathrm{mg} \text { TIW PO or IV }\end{array}$ & $\begin{array}{l}\text { - } \quad \text { Various doses of vitamin K; } \\
\text { Deficiency not solely attributed to } \\
\text { cirrhosis (all received at least } 2 \text { antibiotics, } \\
\text { renal insufficiency, and inadequate diet). }\end{array}$ & $\begin{array}{c}\text { All patients with a diagnosed vitamin K } \\
\text { deficiency exhibited a response to therapy } \\
\text { 4-6 h after infusion and complete correction } \\
\text { of coagulopathy within } 12 \mathrm{~h}\end{array}$ \\
\hline $\begin{array}{l}\text { Pereira et al. [37] } \\
\quad \text { (2005) }\end{array}$ & $\begin{array}{l}\text { Prospective } \\
\text { randomized, } \\
\text { double-blind, } \\
\text { single-center }\end{array}$ & $\begin{array}{l}\mathrm{N}=49 \\
\text { Patients } 16 \text { to } 73 \text { years old with or } \\
\text { at high risk of developing acute } \\
\text { liver failure }\end{array}$ & $\begin{array}{l}10 \mathrm{mg} \text { IV vitamin K vs. } 10 \mathrm{mg} \text { PO } \\
\text { vitamin K vs. placebo }\end{array}$ & $\begin{array}{l}\text { - } \quad \text { Assessed acute liver failure }(76 \% \text { with } \\
\text { acetaminophen hepatotoxicity); } \\
\text { - Mean INR on admission of } 6.4 \text {. }\end{array}$ & $\begin{array}{l}\text { Minority of patients with severe acute liver } \\
\text { dysfunction have a subclinical vitamin K } \\
\text { deficiency; this is corrected by a single dose } \\
\text { of IV vitamin K. While } 94 \% \text { of patients } \\
\text { receiving IV vitamin K had increased serum } \\
\text { vitamin K, only } 20 \% \text { who received PO had } \\
\text { increased serum vitamin K }\end{array}$ \\
\hline Saja et al. [41] (2012) & $\begin{array}{l}\text { Prospective cohort, } \\
\text { multicenter }\end{array}$ & $\begin{array}{c}\mathrm{N}=128 \\
\text { Adult patients (mean age } \\
49 \text { years) recruited into } 4 \text { groups: } \\
\text { inactive hepatitis } \mathrm{B}(n=23) \text {, } \\
\text { chronic viral hepatitis B or C } \\
(n=21) \text {, cirrhosis }(n=24) \text {, or } \\
\text { hepatocellular carcinoma }(n=21)\end{array}$ & $\begin{array}{c}\text { Vitamin K } 10 \mathrm{mg} \text { SQ once }(n=89) \\
\text { vs. no vitamin K administration } \\
(n=39 \text { healthy individuals, mean } \\
\text { age } 38 \text { years })\end{array}$ & $\begin{array}{l}\text { - } \quad \text { Vitamin K-dependent factors were only } \\
\text { measured twice (baseline and at } 72 \mathrm{~h} \text { ); } \\
\text { - } \quad \text { Vitamin K administered SQ instead of IV; } \\
\text { Baseline confounding. }\end{array}$ & $\begin{array}{l}\text { SQ vitamin K in patients with advanced } \\
\text { liver dysfunction resulted in very minimal, } \\
\text { likely clinically insignificant improvement } \\
\text { in PT only (no improvement of FVII, } \\
\text { protein C or S) in cirrhosis group }\end{array}$ \\
\hline $\begin{array}{l}\text { Meyer et al. [43] } \\
\quad(2016)\end{array}$ & $\begin{array}{l}\text { Retrospective cohort, } \\
\text { single-center }\end{array}$ & $\begin{array}{l}\mathrm{N}=276 \\
\geqq 18 \text { years old (mean age } \\
55 \text { years) with cirrhosis }\end{array}$ & $\begin{array}{c}\text { Vitamin K median } 5 \mathrm{mg} \text { dose } \\
(n=130) \text { vs. no vitamin } \mathrm{K} \\
(n=146)\end{array}$ & $\begin{array}{l}\text { - } \quad \text { Various doses and duration of vitamin K; } \\
\text { Varying routes of administration }(13.1 \% \\
\text { IV, } 36 \% \text { PO, } 16.9 \% \mathrm{SQ} \text {, and } 33.8 \% \\
\text { combination); } \\
\text { - Included patients who received blood } \\
\text { products, significantly more in the } \\
\text { vitamin K group ( } 60 \% \text { vs. } 25 \%) .\end{array}$ & $\begin{array}{l}\text { Vitamin K administration had no significant } \\
\text { effect on INR }\end{array}$ \\
\hline $\begin{array}{l}\text { Rivosecchi et al. [42] } \\
\qquad(2017)\end{array}$ & $\begin{array}{l}\text { Retrospective } \\
\text { descriptive study, } \\
\text { single-center }\end{array}$ & $\begin{array}{c}\mathrm{N}=96 \\
\text { Adult patients (mean age } \\
54 \text { years, } 52 \% \text { in ICU) with } \\
\text { cirrhosis who received at least } \\
\text { one dose of IV vitamin K with a } \\
\text { baseline INR of }>1.5 \text { and at least } \\
\text { one repeat INR } 6-24 \text { h post } \\
\text { administration }\end{array}$ & IV vitamin $\mathrm{K}$ & $\begin{array}{l}\text { - Various doses of vitamin } \mathrm{K}(81 \% 10 \mathrm{mg} \\
\text { and } 17 \% 5 \mathrm{mg}) ; \\
\text { No standardized time to repeat INR after } \\
\text { vitamin } \mathrm{K} \text { administration (mean } 10 \mathrm{~h}) ; \\
21.9 \% \text { with active bleeding but } 45 \% \\
\text { received FFP. }\end{array}$ & $\begin{array}{l}\text { Vitamin K may not be beneficial to correct } \\
\text { coagulopathy (only } 16.7 \% \text { met primary } \\
\text { endpoint of } 30 \% \text { decrease in INR or } \\
\text { INR } \leqq 1.5 \text {; higher INR elevations are more } \\
\text { likely to have an effective response) }\end{array}$ \\
\hline $\begin{array}{l}\text { Sulaiman et al. [39] } \\
\qquad(2021)\end{array}$ & $\begin{array}{l}\text { Retrospective } \\
\text { observational study, } \\
\text { single-center }\end{array}$ & $\begin{array}{l}\qquad \mathrm{N}=98 \\
\text { Adult ICU patients (mean age } \\
61 \text { years) with hepatic disease } \\
\text { (INR } \geqq 1.5 \text { ) and within } 24 \mathrm{~h} \text { of } \\
\text { ICU admission }\end{array}$ & $\begin{array}{l}\text { Vitamin K administration vs. no } \\
\text { vitamin K }\end{array}$ & $\begin{array}{l}\text { - Unclear what proportion of patients had } \\
\text { cirrhosis; } \\
\text { - Various doses of vitamin K (median } 10 \mathrm{mg} \\
\text { for median duration of } 3 \text { days); } \\
\text { - Various routes of administration ( } 93.6 \% \\
\text { received IV). }\end{array}$ & $\begin{array}{l}\text { Vitamin } \mathrm{K} \text { for INR correction was not } \\
\text { associated with the lower incidence of new } \\
\text { bleeding events; however, vitamin } \mathrm{K} \\
\text { reduced INR by a median of } 0.63 \text { after the } \\
\text { first dose (no significant reduction with } \\
\text { subsequent doses) }\end{array}$ \\
\hline
\end{tabular}


Table 2. Recommendations based on pharmacokinetics of varying vitamin $\mathrm{K}$ formulations.

\begin{tabular}{|c|c|c|c|c|}
\hline Route & PO & IV & SC & IM \\
\hline BBW & None & $\begin{array}{l}\text { Fatal } \\
\text { hypersensitivity } \\
\text { reactions }\end{array}$ & None & $\begin{array}{l}\text { Fatal } \\
\text { hypersensitivity } \\
\text { reactions }\end{array}$ \\
\hline Adverse effects & \multicolumn{3}{|c|}{$\begin{array}{l}\text { Diaphoresis, cyanosis, dizziness, flushing, hypotension, } \\
\text { tachycardia }\end{array}$} & $\begin{array}{c}\text { Hematoma } \\
\text { formation, } \\
\text { diaphoresis, } \\
\text { cyanosis, dizziness, } \\
\text { flushing, } \\
\text { hypotension, } \\
\text { tachycardia }\end{array}$ \\
\hline Absorption & $\begin{array}{c}\text { Unlikely in } \\
\text { advanced liver } \\
\text { disease }\end{array}$ & Readily & Variable & Readily \\
\hline Time to $\downarrow$ INR & $\begin{array}{c}6 \text { to } 10 \mathrm{~h} \\
\text { (peak } 24 \text { to } 48 \mathrm{~h})\end{array}$ & $\begin{array}{c}1 \text { to } 2 \mathrm{~h} \\
\text { (peak } 12 \text { to } 24 \mathrm{~h} \text { ) }\end{array}$ & $\begin{array}{c}\text { Variable } \\
\text { (peak at } 72 \mathrm{~h} \text { ) }\end{array}$ & Variable \\
\hline $\begin{array}{l}\text { Recommendation } \\
\text { for cirrhosis- } \\
\text { associated } \\
\text { coagulopathy }\end{array}$ & $\begin{array}{l}\text { Consider avoiding } \\
\text { use } \\
1,2\end{array}$ & $\begin{array}{c}\text { Consider in } \\
\text { actively bleeding } \\
\text { or critically ill } \\
\text { patients with } \\
\text { vitamin } \mathrm{K} \\
\text { deficiency } 1,3\end{array}$ & $\begin{array}{l}\text { Consider avoiding } \\
\text { use } \\
1,4\end{array}$ & $\begin{array}{l}\text { Should be avoided } \\
\qquad 1,5\end{array}$ \\
\hline
\end{tabular}

${ }^{1}$ Routine use of phytonadione to correct INR in cirrhotic patients not taking warfarin should be avoided due to the lack of proven benefits. ${ }^{2}$ PO formulation is unlikely to be absorbed in cirrhotic patients; however, there is minimal risk to its use. Consider avoiding its use in patients who are actively bleeding or those who are critically ill in favor of using IV formulation. ${ }^{3}$ IV formulation will correct vitamin K deficiency the fastest $(\sim 12 \mathrm{~h})$; however there is a risk of fatal hypersensitivity. The potential benefit likely outweighs the risk in critically ill or actively bleeding cirrhotic patients if they have a vitamin K deficiency; the risk of hypersensitivity can be minimized by limiting the infusion rate to $1 \mathrm{mg} / \mathrm{min}$ or less. ${ }^{4} \mathrm{SC}$ formulation has variable bioavailability, but likely more than $\mathrm{PO}$ formulation in cirrhotic patients due to absorption issues; consider SC as an alternative to PO formulation. Consider avoiding its use in patients who are actively bleeding or those who are critically ill in favor of using IV formulation. ${ }^{5} \mathrm{IM}$ formulation has the same risk of fatal hypersensitivity as the IV formulation; it also has the risk of hematoma. There is no advantage to use IM over IV, so it should be avoided.

Author Contributions: Conceptualization, S.J. and A.F.; methodology, S.J., L.H., and A.F; investigation, S.J., L.H., and A.F.; resources, S.J., L.H., and A.F.; data curation, S.J., L.H., and A.F.; writingoriginal draft preparation, S.J., L.H., and A.F.; writing-review and editing, S.J., L.H., and A.F.; supervision, A.F. All authors have read and agreed to the published version of the manuscript.

Funding: There is no external funding.

Institutional Review Board Statement: Not applicable.

Informed Consent Statement: Not applicable.

Conflicts of Interest: The authors declare no conflict of interest.

\section{References}

1. Aldrich, S.M.; Regal, R.E. Routine Use of Vitamin K in the Treatment of Cirrhosis-Related Coagulopathy: Is it A-O-K? Maybe Not, We Say. Pharm. Ther. 2019, 44, 131-136. Available online: https:/ /www.ncbi.nlm.nih.gov/pubmed/30828234 (accessed on 31 October 2021).

2. Gines, P.; Krag, A.; Abraldes, J.G.; Sola, E.; Fabrellas, N.; Kamath, P.S. Liver cirrhosis. Lancet 2021, 398, 1359-1376. [CrossRef]

3. Gines, P.; Sola, E.; Angeli, P.; Wong, F.; Nadim, M.K.; Kamath, P.S. Hepatorenal syndrome. Nat. Rev. Dis Primers 2018, 4, 23. [CrossRef] [PubMed]

4. Ge, P.S.; Runyon, B.A. Treatment of Patients with Cirrhosis. N. Engl. J. Med. 2016, 375, 767-777. [CrossRef] [PubMed]

5. Lisman, T.; Porte, R.J. Rebalanced hemostasis in patients with liver disease: Evidence and clinical consequences. Blood 2010, 116, 878-885. [CrossRef] [PubMed]

6. Roberts, J.R.; Bambha, K. Balanced coagulopathy in cirrhosis-clinical implications: A teachable moment. JAMA Intern. Med. 2014, 174, 1723-1724. [CrossRef]

7. Favaloro, E.J.; Lippi, G.; Koutts, J. Laboratory testing of anticoagulants: The present and the future. Pathology 2011, 43, 682-692. [CrossRef] 
8. Conway, S.E.; Hwang, A.Y.; Ponte, C.D.; Gums, J.G. Laboratory and Clinical Monitoring of Direct Acting Oral Anticoagulants: What Clinicians Need to Know. Pharmacotherapy 2017, 37, 236-248. [CrossRef]

9. Tripodi, A.; Mannucci, P.M. The coagulopathy of chronic liver disease. N. Engl. J. Med. 2011, 365, 147-156. [CrossRef]

10. Bosch, J.; Thabut, D.; Bendtsen, F.; D'Amico, G.; Albillos, A.; Abraldes, J.G.; Fabricius, S.; Erhardtsen, E.; de Franchis, R.; European Study Group on rFVIIa in UGI Haemorrhage. Recombinant factor VIIa for upper gastrointestinal bleeding in patients with cirrhosis: A randomized, double-blind trial. Gastroenterology 2004, 127, 1123-1130. [CrossRef]

11. Bosch, J.; Thabut, D.; Albillos, A.; Carbonell, N.; Spicak, J.; Massard, J.; D’Amico, G.; Lebrec, D.; de Franchis, R.; Bendtsen, F.; et al. Recombinant factor VIIa for variceal bleeding in patients with advanced cirrhosis: A randomized, controlled trial. Hepatology 2008, 47, 1604-1614. [CrossRef]

12. Lodge, J.P.A.; Jonas, S.; Jones, R.M.; Olausson, M.; Mir-Pallardo, J.; Soefelt, S.; Garcia-Valdecasas, J.C.; McAlister, V.; Mirza, D.F.; for the rFVIIa OLT Study Group. Efficacy and safety of repeated perioperative doses of recombinant factor VIIa in liver transplantation. Liver Transpl. 2005, 11, 973-979. [CrossRef]

13. Planinsic, R.M.; Van Der Meer, J.; Testa, G.; Grande, L.; Candela, A.; Porte, R.J.; Ghobrial, R.M.; Isoniemi, H.; Schelde, P.B.; Erhardtsen, E.; et al. Safety and efficacy of a single bolus administration of recombinant factor VIIa in liver transplantation due to chronic liver disease. Liver Transpl. 2005, 11, 895-900. [CrossRef]

14. Shah, N.L.; Intagliata, N.M.; Northup, P.G.; Argo, C.K.; Caldwell, S.H. Procoagulant therapeutics in liver disease: A critique and clinical rationale. Nat. Rev. Gastroenterol. Hepatol. 2014, 11, 675-682. [CrossRef]

15. Tripodi, A.; Salerno, F.; Chantarangkul, V.; Clerici, M.; Cazzaniga, M.; Primignani, M.; Mannuccio Mannucci, P. Evidence of normal thrombin generation in cirrhosis despite abnormal conventional coagulation tests. Hepatology 2005, 41, 553-558. [CrossRef]

16. Tripodi, A.; Primignani, M.; Chantarangkul, V.; Clerici, M.; Dell'Era, A.; Fabris, F.; Salerno, F.; Mannucci, P.M. Thrombin generation in patients with cirrhosis: The role of platelets. Hepatology 2006, 44, 440-445. [CrossRef]

17. Northup, P.G.; McMahon, M.M.; Ruhl, A.P.; Altschuler, S.E.; Volk-Bednarz, A.; Caldwell, S.H.; Berg, C.L. Coagulopathy does not fully protect hospitalized cirrhosis patients from peripheral venous thromboembolism. Am. J. Gastroenterol. 2006, 101, 1524-1528, quiz 1680. [CrossRef]

18. Dabbagh, O.; Oza, A.; Prakash, S.; Sunna, R.; Saettele, T.M. Coagulopathy does not protect against venous thromboembolism in hospitalized patients with chronic liver disease. Chest 2010, 137, 1145-1149. [CrossRef]

19. Sogaard, K.K.; Horvath-Puho, E.; Gronbaek, H.; Jepsen, P.; Vilstrup, H.; Sorensen, H.T. Risk of venous thromboembolism in patients with liver disease: A nationwide population-based case-control study. Am. J. Gastroenterol. 2009, 104, 96-101. [CrossRef]

20. Qi, X.; Han, G.; Fan, D. Management of portal vein thrombosis in liver cirrhosis. Nat. Rev. Gastroenterol. Hepatol. 2014, 11, 435-446. [CrossRef]

21. Gish, R.G.; Regenstein, F.G.; Flamm, S.L.; Stravitz, R.T.; Brothers, J.M. Guidance for Coagulation Management in Patients with Acute or Chronic Liver Failure. Gastroenterol. Hepatol. 2021, 17, 3-26. Available online: https://www. gastroenterologyandhepatology.net/supplements / guidance-for-coagulation-management-in-patients-with-acute-or-chronicliver-failure/ (accessed on 31 October 2021).

22. Ramotar, K.; Conly, J.M.; Chubb, H.; Louie, T.J. Production of menaquinones by intestinal anaerobes. J. Infect. Dis. 1984, 150, 213-218. [CrossRef]

23. Shearer, M.J.; McBurney, A.; Barkhan, P. Studies on the absorption and metabolism of phylloquinone (vitamin K1) in man. Vitam. Horm. 1974, 32, 513-542. [CrossRef]

24. Harrison, M.F. The Misunderstood Coagulopathy of Liver Disease: A Review for the Acute Setting. West J. Emerg. Med. 2018, 19, 863-871. [CrossRef]

25. Llibre-Nieto, G.; Lira, A.; Vergara, M.; Solé, C.; Casas, M.; Puig-Diví, V.; Solé, G.; Humanes, A.; Grau, L.; Barradas, J.M.; et al. Micronutrient Deficiencies in Patients with Decompensated Liver Cirrhosis. Nutrients 2021, 13, 1249. [CrossRef]

26. Licata, A.; Zerbo, M.; Como, S.; Cammilleri, M.; Soresi, M.; Montalto, G.; Giannitrapani, L. The Role of Vitamin Deficiency in Liver Disease: To Supplement or Not Supplement? Nutrients 2021, 13, 4014. [CrossRef]

27. Iber, F.L.; Shamszad, M.; Miller, P.A.; Jacob, R. Vitamin K deficiency in chronic alcoholic males. Alcohol. Clin. Exp. Res. 1986, 10, 679-681. [CrossRef]

28. Hunt, B.J. Bleeding and coagulopathies in critical care. N. Engl. J. Med. 2014, 370, 847-859. [CrossRef]

29. Makris, M.; van Veen, J.J.; Maclean, R. Warfarin anticoagulation reversal: Management of the asymptomatic and bleeding patient. J. Thromb. Thrombolysis 2010, 29, 171-181. [CrossRef]

30. Britt, R.B.; Brown, J.N. Characterizing the Severe Reactions of Parenteral Vitamin K1. Clin. Appl. Thromb. Hemost. 2018, 24, 5-12. [CrossRef]

31. Whitling, A.M.; Bussey, H.I.; Lyons, R.M. Comparing different routes and doses of phytonadione for reversing excessive anticoagulation. Arch. Intern. Med. 1998, 158, 2136-2140. [CrossRef] [PubMed]

32. Raj, G.; Kumar, R.; McKinney, W.P. Time course of reversal of anticoagulant effect of warfarin by intravenous and subcutaneous phytonadione. Arch. Intern. Med. 1999, 159, 2721-2724. [CrossRef] [PubMed]

33. Crowther, M.A.; Douketis, J.D.; Schnurr, T.; Steidl, L.; Mera, V.; Ultori, C.; Venco, A.; Ageno, W. Oral vitamin K lowers the international normalized ratio more rapidly than subcutaneous vitamin $\mathrm{K}$ in the treatment of warfarin-associated coagulopathy. A randomized, controlled trial. Ann. Intern. Med. 2002, 137, 251-254. [CrossRef] [PubMed] 
34. Nee, R.; Doppenschmidt, D.; Donovan, D.J.; Andrews, T.C. Intravenous versus subcutaneous vitamin K1 in reversing excessive oral anticoagulation. Am. J. Cardiol. 1999, 83, 286-288. [CrossRef]

35. Riegert-Johnson, D.L.; Volcheck, G.W. The incidence of anaphylaxis following intravenous phytonadione (vitamin K1): A 5-year retrospective review. Ann. Allergy Asthma Immunol. 2002, 89, 400-406. [CrossRef]

36. Rich, E.C.; Drage, C.W. Severe complications of intravenous phytonadione therapy. Two cases, with one fatality. Postgrad. Med. 1982, 72, 303-306. [CrossRef]

37. Pereira, S.P.; Rowbotham, D.; Fitt, S.; Shearer, M.J.; Wendon, J.; Williams, R. Pharmacokinetics and efficacy of oral versus intravenous mixed-micellar phylloquinone (vitamin K1) in severe acute liver disease. J. Hepatol. 2005, 42, 365-370. [CrossRef]

38. Amarapurkar, P.D.; Amarapurkar, D.N. Management of coagulopathy in patients with decompensated liver cirrhosis. Int. J. Hepatol. 2011, 2011, 695470. [CrossRef]

39. Sulaiman, K.A.; Mutairi, M.A.; Harbi, O.A.; Duraihim, A.A.; Aldosary, S.; Khalil, H.A.; Shaya, A.A.; Harbi, S.A.; Alotaibi, N.; Bekairy, A.; et al. Appropriateness of Using Vitamin K for the Correction of INR Elevation Secondary to Hepatic Disease in Critically ill Patients: An Observational Study. Clin. Appl. Thromb. Hemost. 2021, 27, 10760296211050923. [CrossRef]

40. Alperin, J.B. Coagulopathy caused by vitamin K deficiency in critically ill, hospitalized patients. JAMA 1987, 258, 1916-1919. Available online: https:// www.ncbi.nlm.nih.gov/pubmed/3656602 (accessed on 31 October 2021). [CrossRef]

41. Saja, M.F.; Abdo, A.A.; Sanai, F.M.; Shaikh, S.A.; Gader, A.G. The coagulopathy of liver disease: Does vitamin K help? Blood Coagul. Fibrinolysis 2013, 24, 10-17. [CrossRef]

42. Rivosecchi, R.M.; Kane-Gill, S.L.; Garavaglia, J.; MacLasco, A.; Johnson, H. The effectiveness of intravenous vitamin K in correcting cirrhosis-associated coagulopathy. Int. J. Pharm. Pract. 2017, 25, 463-465. [CrossRef]

43. Meyer, A.V.; Green, M.; Pautler, H.M.; Korenblat, K.; Deal, E.N.; Thoelke, M.S. Impact of Vitamin K Administration on INR Changes and Bleeding Events among Patients with Cirrhosis. Ann. Pharmacother. 2016, 50, 113-117. [CrossRef] 